\title{
Chaikovsky and the Pantomime of Derision ${ }^{1}$
}

$\mathcal{A}$

fter thirty years of teaching and writing about Russian literature and culture, I've discovered a principle that is something halfway between a paradox and a parlor game. It amounts to the question: what do prerevolutionary Russia and homosexuality have in common? Answer: both are regarded by many people in this country as rather distasteful topics about which they'd rather not hear. And both are discussed with great vehemence and self-assurance by people who know little or nothing about them. I can think of no other subjects to which this situation would apply. We cannot imagine anyone writing or lecturing about, say, Shakespeare or nuclear physics or even home gardening without first gaining some firsthand knowledge about these things. Yet, for much of my life, I've been hearing and reading people holding forth on either homosexuality or Russia's pre-October Revolution past from positions of either partial or total ignorance.

Thus, when Boris Yeltsin was elected president of the Russian Republic (before the disintegration of the Soviet Union), then-president George H. W. Bush took to calling him the first man ever elected to office in Russian history. As far back as the fourteenth and fifteenth centuries, however, the city of Novgorod in the north of Russia was an independent mercantile republic which chose its aldermen and other officials by popular elections. Just before its subjugation by Moscow in the 1470s, Novgorod even had a woman mayor, Marfa Boretskaya. During Russia's parliamentary period, 1905-17, hundreds of representatives were elected all over the country and sent to the State Duma. Between the Revolutions of February and October 1917, there were democratically elected mayors in both Moscow and St. Petersburg. Hundreds of deputies, from

1 Originally published as "Chaikovskii and the Pantomime of Derision" in O Rus!: Studia Litteraria Slavica in Honorem Hugh McLean, ed. Simon Karlinsky, James L. Rice, and Barry P. Sherr (Oakland: Berkeley Slavic Specialties, 1995), 47-56. 
all over the country, came to the Constituent Assembly at which they were to choose the form of postrevolutionary government in Russia. All this makes Boris Yeltsin not the first Russian elected to office, as President Bush would have had it, but perhaps the seven-thousandth.

As for instances of discussing homosexuality by people who know nothing at all about it, one could quote quite a selection, from Maksim Gorky's "Destroy homosexuality and fascism will disappear from this world" to Anita Bryant's memorable "They cannot reproduce, so they have to recruit." ${ }^{2}$ One area where the lack of information on prerevolutionary Russia and the lack of understanding about homosexuality converge into a focus is the study of the life and music of the great composer Pyotr Ilich Chaikovsky, who lived from 1840 to 1893 . His music was appreciated and loved in his lifetime, both in his country and abroad. It was performed by the finest orchestras, soloists, and opera companies of his time (as it still is). Chaikovsky was invited to Cambridge University in England to receive an honorary doctorate, and travelled to New York to conduct his music for the opening of Carnegie Hall.

Chaikovsky was also a life-long homosexual, something that was generally known through the grapevine when he was alive. The situation of Russian homosexuals in the last decades of the nineteenth century was more similar to the one in France (the country where many gay Englishmen, threatened with disclosure or scandal, would flee throughout the nineteenth century) than the one in Germany, England, or the United States. For example, during the trial of Oscar Wilde in 1895, two years after Chaikovsky's death, the press of the English-speaking countries unanimously wrote of Wilde with revulsion and contempt. But the Russian press, like the press in France, took Oscar Wilde's side, seeing his case as persecution of a talented artist by the hypocritical and puritanical British authorities.

If you study the period, you find many prominent homosexuals, quite a few of them lesbians, in society, in the arts, and at the imperial court. ${ }^{3}$

2 Maksim Gor'kii, "Proletarskii gumanizm," in Sobranie sochinenii v 30 tomakh [Collected writings in 30 volumes], vol. 27 (Moscow: Gosizdat, 1953), 238. This essay originally appeared in both Pravda and Izvestiia on 23 May 1934.

3 Simon Karlinsky, "Russia's Gay Literature and Culture: The Impact of the October Revolution," in Hidden from History: Reclaiming the Gay and Lesbian Past, ed. Martin Bauml Duberman, Martha Vicinus, and George Chauncey, Jr. (New York: New American Library, 1989), 347-64 and 552-59. 
At the apex of the gay pyramid stood the Grand Duke Sergei Aleksandrovich, the brother of Tsar Alexander III and the uncle of Nicholas II. The Grand Duke Sergei was quite open about his orientation, bringing his current lover to court functions, parades, balls, and the theater and opera. One of the Paris newspapers, announcing his visit to that city, wrote that the grand duke was accompanied by his mistress, Mr. So-and-so. ${ }^{4}$ The reactionary editor and newspaper publisher Prince Vladimir Meshchersky, whom Chaikovsky knew from school, was openly gay and a valued advisor of the last two tsars. When Meshchersky got into major trouble after seducing a bugle boy from the imperial marching band, Alexander III had the case quashed and the witnesses silenced. ${ }^{5}$ All this needs to be pointed out because so many biographies of Chaikovsky stress his constant fear of exposure and his resulting depressed state during much of his life.

This is a widespread view, to which I myself used to subscribe before I learned how wrong it was. In a survey of Russian gay history published eighteen years ago, I wrote that "Chaikovsky's oft-described life was a continual round of pain, fear of exposure and desperate sporadic efforts to change his inner nature."6 Eventually I came to understand that this popular image was not factual. It was definitively demolished with the publication of Aleksandr Poznansky's thoroughly researched biography Tchaikovsky: The Quest for the Inner Man (see note 5). This book was especially important, coming as it did after two decades, the 1970s and the 1980s, when the field of Chaikovsky studies in English came to be dominated by people ignorant of both Russian history and the phenomenon of homosexuality.

Chaikovsky's first biographer was his younger brother Modest. It was in Modest's St. Petersburg apartment that Chaikovsky died of complications from cholera on Sunday, 25 October 1893. Late in the evening of

4 Alexander Poznansky, “Tchaikovsky's Suicide: Myth and Reality," 19th-Century Music 11, no. 3 (Spring 1988): 203.

5 Alexander Poznansky, Tchaikovsky: The Quest for the Inner Man (New York: Schirmer, 1991), 235ff. and 482ff.

6 Simon Karlinsky, "Russia's Gay Literature and History (1 $11^{\text {th }}-20^{\text {th }}$ Centuries)," Gay Sunshine, nos. 29/30 (Summer/Fall 1976): 1-7. [See Gay Sunshine, no. 31 (Winter 1977) for polemics about this piece and correction of errors. A revised version is in Gay Roots: Twenty Years of Gay Sunshine (San Francisco: Gay Sunshine Press, 1991), 81-104.-Ed.] 
the 20th, the composer had supper at Leiner's restaurant, where, as it was shown later, he was served a glass of unboiled water. The symptoms of the illness first appeared the next morning, but the composer and his brother both assumed it was a case of upset stomach, something from which Chaikovsky often suffered. There was a cholera epidemic in the city and the water supply of St. Petersburg was known to have been contaminated with cholera bacilli.

Many biographers of Chaikovsky believed that his death could be blamed on the negligence of Modest Chaikovsky, who was supposedly preoccupied with the rehearsals of his new comedy and did not get medical aid for his brother until it was too late. But as the recent reconstruction of the composer's illness and death by Valery Sokolov (based in part on the unpublished book on the same subject by the microbiologist Nikolai Blinov) shows, Modest brought in two of the most distinguished physicians in St. Petersburg, the brothers Vasily and Lev Bertenson, on the very day that the cholera symptoms appeared. According to Sokolov, cholera was cured by 23 October, but it had weakened Chaikovsky's heart and, especially, kidneys, leading to uremia, of which he actually died. ${ }^{7}$

As Poznansky's book shows, rumors of foul play began almost at the time of Chaikovsky's funeral. Journalists accused his doctors of lack of competence. Cholera was considered the illness of the poor who lived in unsanitary conditions. The only known path of infection was ingesting food or water contaminated by human excrement. How could the affluent and universally admired composer, who was sure to have used only cooked food and boiled water, have gotten cholera? Rumors were concocted that the composer had deliberately played Russian roulette with his life by drinking a glass of unboiled water (an idea to which George Balanchine subscribed). ${ }^{8}$ Actually, the composer was in fine shape when the illness struck-making hotel reservations in towns where he was to conduct in the next few weeks and writing friends whom he hoped to visit.

A powerful stimulus for the rumor mill was provided by the composer's last work, Symphony No. 6, the "Pathétique," whose first perfor-

7 Valerii Sokolov, “Do i posle tragedii: Smert' P. I. Chaikovskogo v dokumentakh," Znamia, November 1993, 148-49.

8 Solomon Volkov, Balanchine's Tchaikovsky (New York: Simon and Schuster, 1985), 219. 
mance he had conducted about ten days before his death. Received with incomprehension and indifference when it was premiered by Chaikovsky, the Sixth Symphony was played at a memorial concert two weeks after his death, and it was now read as Chaikovsky's farewell to life, a kind of musical suicide note and, later, as a depiction of a lifetime of wretchedness entailed by living a homosexual life. By the end of the 1890s, the sexologist Havelock Ellis in England had dubbed the "Pathétique" "the homosexual tragedy symphony."

Brother Modest's biography appeared in three volumes at the turn of the century. Modest's once-popular plays are now firmly forgotten, but his biography still remains an attractive piece of writing and an indispensable source about Chaikovsky's life. ${ }^{10}$ But as Poznansky rightly warns in his book, it is a slanted source. Being a man of his time, Modest Chaikovsky resolutely concealed his own and his brother's homosexuality from the readers. By doing so, he also omitted some of the happiest periods and relationships in his brother's life: his rewarding liaisons with his one-time classmate Sergei Kireev and with the violinist Iosif Kotek, his durable affair with his valet Alyosha (Aleksei Sofronov) and so on.

To learn about such things, we have to turn to Chaikovsky's personal diaries, published in 1923 by his other brother, Ippolit, or to the remarkably frank and well-annotated volume of correspondence with his younger brothers and other relatives that somehow slipped past the Soviet censorship as late as 1940 (the editors were punished and the volume withdrawn, but not before copies found their way to libraries in the West). ${ }^{11}$ Modest's biography appeared in 1906 in English in an abridged translation by Rosa Newmarch. This remained the standard source in English, a biography full of holes, with many episodes, such as the composer's brief, disastrous marriage, making no sense at all in Modest's and Rosa Newmarch's telling.

However, Chaikovsky's sexual orientation was generally known to scholars in the West. This awareness must surely have contributed to the

9 Herbert Weinstock, Tchaikovsky (New York: Alfred A. Knopf, 1943), 365.

10 Modest Chaikovskii, Zhizn' Petra Il'icha Chaikovskogo (Moscow and Leipzig: Jurgenson, 1900-3).

11 Petr Chaikovskii, Dnevniki [Diaries], 1873-1891 (Moscow and Petrograd: Glavlit, 1923); idem, Pis'ma k rodnym [Letters to relatives] (Moscow: Gos. muzykal'noe izdvo, 1940). 
judgment of his music by some heavyweights of mid-twentieth-century musicology: Donald Francis Tovey (who considered him "a composer of light music" who cannot handle a symphonic movement); or Paul Henry Lang: "The development of his themes often becomes hysterical."12 This whole critical attitude has been described by the scholar Henry Zajaczkowski as "the musicological pantomime of derision that has passed as serious critical assessment of [Chaikovsky's] music for so many years."13

The low point of this mid-century pantomime was reached in the collection of essays edited by Gerald Abraham published in 1946, reissued in 1974, and available at most libraries. In the introductory biographical essay by the then well-known critic Edward Lockspeiser, we read of a life of fear, despondency, and self-pity and of "neurotic character" that "drove him into homosexuality with all its attendant complications of furtiveness, deception and guilt." And then: "It is the music to gorge on, shameless in its sensuousness and splendor. And it was no accident that such music was conceived by a warped neurotic, shy and tortured."14 (Except for homosexuality, not a single trait mentioned by Lockspeiser is confirmed by any memoir about Chaikovsky or by his own diaries and letters.) Some of the other contributors to Abraham's volume played variations on the theme of how inept a composer Chaikovsky was due to his neurosis: he had no sense of form, could not put a concerto together properly, did not know how to orchestrate, and so forth. ${ }^{15}$

There were other midcentury biographies of Chaikovsky that did not see his private life as a handicap to his talent or to his technical abi-

12 Richard Taruskin, “Tchaikovsky, Fallen from Grace," New York Times, 30 June 1991.

13 Henry Zajaczkowski, Tchaikovsky's Musical Style (Ann Arbor: UMI Research, 1987), vii.

14 Gerald Abraham, ed., The Music of Tchaikovsky (New York: W. W. Norton, 1946), 9-23.

15 In addition to the cited biographical sketch by Lockspeiser, Abraham's collection also contains Eric Blom's chapter "Works for Solo Instruments and Orchestra," where the author seeks to vindicate Nikolai Rubinstein's initial judgment of the First Piano Concerto (known from Chaikovsky's oft-cited letter to Nadezhda von Meck) as "bad as a whole," "worthless and repellently trivial"; "Miscellaneous Orchestral Works" by Ralph W. Wood, with frequent references to the composer's supposed ineptitude and vulgarity and the pronouncement that Francesca da Rimini is "really a very low-grade piece of music"; and a section "The Ballets" by Edwin Evans, which is so uninformed and error-ridden as to be practically worthless. 
lity. Such were, for example, the books in English by Herbert Weinstock (1943), and by John Gee and Elliott Selby (1960), authors who did not see Chaikovsky's homosexuality as something that gave them the right to despise him. ${ }^{16}$ But they did follow the general trend of perceiving the composer's story as a lifetime of unrelieved pain and suffering in his closet. A rare instance of a book written with understanding of Russian society during the period when Chaikovsky lived was the biographie romancée written by the exiled Russian poet and novelist Nina Ber-

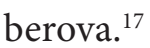

By the 1930s, there were rumors that Chaikovsky did not die of cholera, but was forced to commit suicide because of his homosexuality. These rumors came in many versions. The composer, supposedly, got involved sexually with a son or a nephew of the tsar, or of some noble family, or of the yard-keeper of the building where he lived. He was then given a choiceusually by the tsar, but sometimes by the father or the uncle of the young man: "suicide or Siberia!" The purveyors of these rumors did not know that Alexander III, whose brother and closest adviser were openly gay, was not likely to have taken such an attitude. With the postrevolutionary clampdown on the topic of homosexuality, people forgot the conditions that had existed in the 1890s. Berberova's research revealed that people who knew Chaikovsky and were near him when he died remembered his death from cholera. The suicide version was always asserted by people who did not know the composer, but had heard the story from someone they thought reliable.

But things were to get still worse later in the century. With the publication of Tchaikovsky by the Englishman Edward Garden in 1973, the real dark ages of Chaikovsky studies began. At a time when a great deal of information about variant forms of sexuality was becoming known even to the general public, what Garden offered was not only what today is called homophobia, but a sort of militant ignorance of the entire subject. Since Chaikovsky was a homosexual, wrote Garden, "he was unable to feel sexually aroused," and was thus continuously frustrated. He also could not "establish a firm, constant and loving relationship

\footnotetext{
16 Weinstock, Tchaikovsky; John Gee and Elliott Selby, The Triumph of Tchaikovsky: A Biography (New York: Vanguard, 1960).

17 Nina Berberova, Chaikovskii: Istoriia odinokoi zhizni (Berlin: Petropolis, 1936).
} 
with any other human being." The result was "a propensity for nervous breakdowns unparalleled by any other great composer," which repeatedly brought him to the verge of insanity. Much of Chaikovsky's music is marred for Garden by his "morbid inversion" or "by the frustrations of his endemic homosexuality."18

In 1978, Garden's associate, another senior English musicologist, David Brown, published the first volume of his four-volume critical and biographical study, completed with the appearance of its fourth volume in 1991. Brown established his point of view in his first volume, where he wrote in a simplistic Freudian vein that the death of the composer's mother when he was a teenager led to the "growths of psychological abnormality which insidiously bound themselves round him, constricting, distorting and unbalancing his emotional life," thus preventing him forever from forming any close personal relationships. ${ }^{19}$ Of course, there were relationships with various men documented in Chaikovsky's diaries and letters, but Garden's and Brown's detestation of the entire topic led them to ignore this. Like Garden before him, Brown tried to establish causal relationships between what he saw as flaws in Chaikovsky's music (he judged about two-thirds of his output artistic failures) and the pathology of his orientation.

The third recent obfuscator to muddy the understanding of Chaikovsky's life and music is the Soviet music historian Aleksandra Orlova. She departed for the West in 1979 and within two years became internationally famous through her sensationalist articles about Chaikovsky's death. He did not die of cholera, she claimed, but was forced to take poison by a so-called court of honor convoked by his fellow alumni from the School of Jurisprudence, a kind of junior college he had attended in his youth. These men, whom he had not seen for decades, found out about Chaikovsky's homosexuality and condemned him to death for besmirching the uniform of their school. Then, teste Orlova, a monstrous conspiracy, involving the composer's family, three distinguished doctors, the police, and the tsar's court covered up the suicide and palmed it off as a cholera infection. And how does Aleksandra Orlova know all this? Why,

18 Edward Garden, Tchaikovsky (London: J. M. Dent, 1973)

19 David Brown, Tchaikovsky: A Biographical and Critical Study, vol. 1, The Early Years, 1840-1874 (London: Gollancz, 1978), 50. 
she was told in 1966 by a man named Aleksandr Voitov, who had heard it as a teenaged boy in 1913 from the widow of one of the members of the "court of honor," whose husband had died in 1902.20

It was all, of course, one of those "death or Siberia" rumors that Nina Berberova had investigated back in the 1930s, rumors that cannot ever be traced to anyone who was anywhere near Chaikovsky at the time of his death, rumors whose acceptance depends on total ignorance of the situation of Chaikovsky or of the homosexuals of his time. But in the conspiracy-hungry West, Orlova's claims were eagerly accepted. David Brown became her ally and placed her version of the events in the authoritative New Grove Dictionary of Music and Musicians and into two other music dictionaries, published between 1983 and 1986. ${ }^{21}$

Clearly, Orlova's version satisfied people like David Brown and Edward Garden, who believe that all homosexuals lead lives of ceaseless misery, from which suicide offers a welcome escape. Orlova herself belongs to this group: as she has written, Chaikovsky was "tormented by his anomaly throughout his life, the anomaly that was a calamity, a curse laid upon him by fate." And a little further: "Being a highly decent and honorable man, he regarded his anomaly as a disgrace that could never be effaced." 22 (Once again, there is no support for this in any document that stems from Chaikovsky or his contemporaries.) Orlova believes that the suffering heroines of Chaikovsky's operas, especially the suicidal Liza in Pikovaia dama, are musical portrayals of the composer's ceaseless pain and despair. Curious, isn't it, that no one ever says this of the suffering women in the operas by Verdi and Puccini?

As Aleksandr Poznansky showed in his 1988 essay, all the hypothesizing about Chaikovsky's endless misery and ultimate suicide was based not on the facts of his biography or the content of his music but rather on the widespread myth about how homosexuals were supposed to have fared in the nineteenth century. The suicide version, in particular, was ably refuted by two authors in Russia, who were aware of Poznansky's 1988 essay

20 Alexandra Orlova, “Tchaikovsky: The Last Chapter," trans. David Brown, Music \& Letters 62 (1981): 125-45; idem, Tchaikovsky: A Self-Portrait (Oxford: Oxford University Press, 1990).

21 Poznansky, “Tchaikovsky’s Suicide," 214n3.

22 Aleksandra Orlova, "Tragediia Chaikovskogo i gorbachevskaia glasnost', Novoe russkoe slovo, 25 January 1987. 
and who fully supported his conclusions. ${ }^{23}$ It is indicative of Aleksandra Orlova's and David Brown's scholarly probity that neither she in her 1990 book nor he in the last volume of his Chaikovsky biography made any mention of the considerable number of publications that disagreed with their "misery-cum-suicide" interpretation of the composer's life. ${ }^{24}$

Since the tragic mood of the Sixth Symphony and the seemingly hopeless atmosphere of its last movement have been repeatedly adduced as evidence that in his last work Chaikovsky bid his farewell to life, it might be appropriate to point out that the sketches for this last movement go back at least two years before the symphony's premiere. ${ }^{25}$ Moreover, while working on the Sixth, he made preliminary drafts for his unrealized Seventh Symphony. These drafts eventually ended up as his one-movement, posthumous Third Piano Concerto, an energetic piece of music that does not contain a single despondent passage. If we take the (always dubious) path of reconstructing the man and his character through his music, we have to point out that he left behind not only "Sérénade mélancholique," "Autumn Song," and such possibly uncheerful operas as Evgeny Onegin and Mazepa, but also the radiant First Piano Concerto, the lively comic opera Cherevichki, and his final work for the operatic stage, Iolanta, with its jubilant finale celebrating the heroine's deliverance from blindness. The last major composition before the Sixth Symphony was the coruscating ballet Shchelkunchik (The Nutcracker) - surely a piece of music that the hopeless psychotic described by Lockspeiser, Garden, David Brown, and Orlova could not possibly have composed.

In a somewhat later piece that covered much the same ground as this one, but which appeared in a publication that served a readership with a specific interest in LGBT concerns, SK balanced his account of Chaikovsky's alleged suicide - as a myth created by, and appealing to, homophobia - with a complementary report of its reception in the homosexual community, where it

23 B. S. Nikitin, Chaikovskii: Staroe i novoe (Moscow: Znanie, 1990); Gennadii Shokhman, "Vzgliad s drugikh beregov," Sovetskaia muzyka 6 (1990): 134-41.

24 Orlova, Tchaikovsky: A Self-Portrait; David Brown, Tchaikovsky: A Biographical and Critical Study, vol. 4, The Final Years, 1885-1893 (New York: W. W. Norton, 1991).

25 Nikitin, Chaikovskii, 188. 
was not always greeted with skepticism, but where, in a fashion that was on the face of it surprising (but on reflection less so), was often eagerly appropriated by journalists and activists. He called out for rueful censure the especially erroneous version of the American composer Ned Rorem, who "in the pages of Opera News (1 February 1986) mentioned a 'state-enforced suicide' because of the composer's 'liaison with his nephew.'" As SK perhaps somewhat hyperbolically remarked, the "gay community in America took to the suicide story en masse, as it furnished a famous gay martyr from the past." He pointed with dismay to "an unholy alliance ... between the benighted homophobes in England and gay liberationists and historians in America"-a phenomenon that furnished this essay (largely a review of yet another homophobic British biography) with its title. ${ }^{26}$ With the exception of a dictionary entry published in $2000,{ }^{27}$ this was SK's final contribution to Chaikovsky studies and his last article on music.

26 "Tchaikovsky and the Unholy Alliance," review of Tchaikovsky: A Biography, by Anthony Holden (New York: Random House, 1996), Harvard Gay and Lesbian Review 3 , no. 4 (Fall 1996): 31-33.

27 "Tchaikovsky, Pyotr Ilich (1840-1893)," in Gay Histories and Cultures: An Encyclopedia, ed. George Haggerty (New York: Garland, 2000), 865-66. 